\title{
A Systematic Review of Slash-and-Burn Agriculture as an Obstacle to Future-Proofing Climate Change
}

\author{
Kuok Ho Daniel Tang ${ }^{1}$ and Pow-Seng Yap ${ }^{2 *}$ \\ ${ }^{I}$ Environmental Science Program, Division of Science and Technology, BNU-HKBU UIC, 2000 Jintong Road, \\ Tangjiawan, Zhuhai, GD 519087, China \\ ${ }^{2}$ Department of Civil Engineering, Xi'an Jiaotong-Liverpool University, Suzhou, 215123, China
}

\begin{abstract}
The recent haze affecting Malaysia, Indonesia and Singapore, as well as forest fires in the Amazon have raised global concerns on the debilitating effect of slash-and-burn agricultural practice particularly as nations are joining forces in combating climate change. With slash-and-burn still widely practiced in the developing nations, this literature review aims to examine the drivers of slash-and-burn agriculture and its impacts in terms of greenhouse gas emissions and atmospheric $\mathrm{CO}_{2}$ sequestration, while suggesting alternatives to slash-and-burn agriculture. The review covers more than 80 articles on slash-and-burn agriculture, published mainly over the past 15 years. Slashand-burn agriculture has been survived by the pressure to make a living under inadequate resources, access to market and technologies, a lack of alternative livelihoods as well as loopholes in institutional mechanisms, regulations and enforcement. Slash-and-burn agriculture leads to chemical changes of soil, alteration of soil biota and species richness, and the extent of changes correlates with fallow period after slash-and-burn. Large-scale slash-and-burn for commercial agriculture and livestock farming is the major contributor of greenhouse gases and agricultural intensification shortens fallow period for recovery of ecosystems. Slash-and-burn also impacts the ability of forests to sequester atmospheric $\mathrm{CO}_{2}$ and short fallow period further reduces this ability. This review calls for alternative agricultural practices comprising two approaches namely land preparation and landuse systems, as adaptation and mitigation against climate change. Land preparation consists of mulching, improved forest conversion, mechanized land preparation and slash-and-char system. Land-use systems however are categorized into alternative agrosystems, agroforestry, cultivated pastureland and integrated system of crop-livestock-forests. This review therefore contributes to raising awareness and proposing practical alternatives to slash-and-burn for environmental sustainability.
\end{abstract}

Keywords: agriculture; climate change; greenhouse gases; slash-and-burn

\section{Introduction}

Slash-and-burn agriculture, otherwise known as shifting cultivation is a traditional agricultural practice of many ethnic groups whose origin can be traced to the Neolithic Revolution during which human began to relinquish hunting and gathering for planting crops (Cornell, 2011). The adoption of agriculture then was followed by conversion of forests into farmlands and a common method used for such conversion was slashand-burn. Agriculture was carried out on slashed and burned lands until the soil eventually became unproductive, prompting the farmers to clear new lands (Tschakert et al., 2007). Slash-and-burn agriculture typically involved felling of native vegetation during dry season and letting the felled vegetation dry before burning. The ash from burning fertilized and conditioned the soil for planting at the start of the ensuing rainy season (Vosti and Witcover, 1996).

To date, slash-and-burn agriculture has been abandoned in the most developed regions of the world such as Europe and North America but is still practiced by tribes in the South Asia and Africa such as in Bangladesh, India, Malaysia, Thailand and Congo (Grogan et al., 2012; van Vliet et al., 2012). While providing a fast and cost-effective way to clear a large tract of land for agricultural purposes, slash-and-burn gives rise to environmental concerns. Ziegler et al. (2009) warned of the increased risk of soil erosion, hence leaching of 


\section{Kuok Ho Daniel Tang and Pow-Seng Yap / A Systematic Review of Slash-and-Burn Agriculture as an Obstacle to Future-Proofing Climate Change}

soil nutrients upon shortening the fallow period on slashed and burned lands. Slash-and-burn agriculture also leads to deforestation, loss of biodiversity and susceptibility of farmlands to invasion by noxious plants (van Vliet et al., 2012). With increasing concerns over global climate change and combats against climate change via adaptations and mitigations, slash-and-burn agriculture counteracts such combats by releasing large amount of greenhouse gases (GHGs) into the atmosphere (d'Oliveira et al., 2011). The mean $\mathrm{CO}_{2}$ emitted annually from slash-and-burn agriculture in America, Asia and Africa had been estimated at 295, 241 and 205 $\mathrm{Tg}$, respectively (Silva et al., 2011). In equilibrium, the $\mathrm{CO}_{2}$ emitted from slash-and-burn agriculture would be absorbed and assimilated by crops as they grow, thus not setting the $\mathrm{CO}_{2}$ concentration in the atmosphere off balance in the long term, but equilibrium was rarely the case (Lehsten et al., 2009; Silva et al., 2011). Besides $\mathrm{CO}_{2}$, slash-and-burn agriculture would also emit other GHGs such as carbon monoxide, methane and nitrous oxide (Silva et al., 2011). The estimated annual mean emission of methane from America, Asia and Africa was 1197, 979 and $832 \mathrm{Gg}$, respectively (Silva et al., 2011).

As signatories of the Paris Agreement strive to cap the global temperature rise by $2^{\circ} \mathrm{C}$ with reference to the pre-industrial levels, the continuation of slash-and-burn agriculture either as cultural legacy or a convenient means of land conversion is a definite obstacle to efforts made in future-proofing climate change via the temperature rise window (van Vliet et al., 2012; Christoff, 2016). It is apparent that slash-and-burn agriculture is currently still practiced and probably to an alarming level with the Amazon forest fire and the haze episodes in the Southeast Asia coming into the headlines. The Amazon forest fire was fueled by failing control on deforestation as farmers sidestep legislation (Carvalho et al., 2019). The haze in the Southeast Asia, particularly Indonesia and Malaysia was attributed primarily to land conversion for oil palm plantations and to a smaller extent, subsistence farming (Tan-Soo and Pattanayak, 2019). Nonetheless, there have been very few studies which examine the threats of slash-and-burn agriculture to the efforts and advances made in combating climate change. While much emphasis has been placed on adapting to and mitigating climate change, it is also crucial to probe the persistence of the age-old slash-and-burn agriculture and then make recommendations to reduce the practice.

An examination of literature in the genre of slash-and-burn agriculture reveals numerous studies on the environmental impacts of slash-and-burn agriculture, particularly its effects on soil. Gay-des-Combes et al. (2017) investigated how slash-and-burn altered soil fertility dynamics especially for corn cultivation. Similarly, Kukla et al. (2019) examined the impacts of slash-and-burn agriculture on soil organic and nutrient compositions, and the microbiota of tropical forests. Thomaz (2017) explored the effect of high fire temperature during slash-and-burn on the stability of soil aggregate. There are also studies looking into how slash-and-burn agriculture impacts biodiversity, for instance the soil seed banks in Madagascar (Randriamalala et al., 2015), the birds and trees in the Western Amazon (Socolar et al., 2019) as well as the recovery of vegetation after slashing and burning (Thong et al., 2016). Studies on the impacts of slash-andburn on climate change are far and few. Tinker et al. (1996) reviewed the consequences of slash-and-burn agriculture on climate change while van Vliet et al. (2012) delved into the general impacts of slash-and-burn agriculture as well as trends and drivers of the practice. Kotto-Same et al. (1997) studied the carbon dynamics of slash-and-burn agriculture in Cameroon. Palm et al. (2004) on the other hand, examined alternatives to slash-and-burn agriculture as mitigation of GHGs emissions. In light of the advances made in combating climate change, literature probing the barriers imposed by slash-and-burn agriculture on climate changerelated efforts and progresses are disproportionally few.

With the objectives stated above, this study centers on the review of literature related to the drivers for as well as the current and future trends of slash-and-burn agriculture. It begins with presenting the drivers and trends of slash-and-burn agriculture, followed by examination of the environmental impacts of slash-and-burn agriculture, particularly the implications of increased GHGs emissions and lower sequestration of atmospheric $\mathrm{CO}_{2}$ on climate change. It ends with recommendations for actions against and alternatives to slash-and-burn agriculture to future-proof climate change. The literature review therefore encompassed more than 80 articles in the areas of the drivers for slash-and-burn agriculture, the environmental impacts on slash-and-burn agriculture, the implications of GHGs emission and reduced carbon sequestration potential on climate change, 
and the alternatives to slash-and-burn agriculture. The review focused on literature published in the past 15 years though older literature is included where there is no comparable literature in the last 15 years to support the arguments.

\section{The Drivers for Slash-and-Burn Agriculture}

With soaring demand for agricultural lands and pasture to feed the growing population, deforestation seems to be unstoppable and slash-and-burn practice provides a low-cost and convenient way for removal of large amount of biomass from large tracts of land. At household level, indigenous farmers are driven to slash-andburn agriculture and short fallow due to the pressure to make a living particularly under conditions of inadequate resources often faced by farmers in remote regions of the world (van Vliet et al., 2012). This could be observed among farmers in the Bornean inland which still practice slash-and-burn agriculture owing mainly to the lack of manpower and machinery for land clearing during subsistence farming (Iwata et al., 2003). Braga \& Martensen, (2017) also found limited access to market and agricultural technologies as the predominant reason driving slash-and-burn practice among Amazonian farmers. In many instances, farmers are left with slash-and-burn agriculture as the only means of generating income unless they have alternative ways of livelihood (Vosti and Witcover, 1996). It is likely that they will continue to practice what they have been practicing for generations until they encounter or are sufficiently prepared for alternative sources of income.

According to Vosti \& Witcover (1996), environmental consequences of slash-and-burn agriculture are unlikely to affect decision of the farmers to adopt the agricultural practice unless they feel the severity of the consequences themselves and there is institutional mechanism to transfer the environmental cost to the farmers. In the Malaysian Borneo, though open burning is generally prohibited, slash-and-burn agriculture persists and has been perceived by the indigenous as the norm or convention of agriculture practiced generation after generation. This renders institutional mechanisms and enforcement ineffective (Iwata et al., 2003). The dilemma is also faced by regulators in other nations where slash-and-burn agriculture is still traditional practiced. In Central Kalimantan, Indonesia, maintaining welfare and food security are the main reasons behind forest-cover change and much of the change has been achieved via slash-and-burn practices by the local (Medrilzam et al., 2013).

Persistence of slash-and-burn agriculture has been reported in many countries, mainly Central Africa and Madagascar followed by Central and Latin America (van Vliet et al., 2012). Southeast Asia and East African also demonstrated increases of slash-and-burn agriculture and this was often driven by economic and demographic factors (van Vliet et al., 2012). The increasing rural population and their adoption of mainstream economy propel slash-and-burn agriculture in Madagascar, while development policies and land law that favor ranching and agriculture in Brazil drive slash-and-burn agriculture there (Salisbury and Schmink, 2007; van Vliet et al., 2012). This is supported by Braga \& Martensen (2017) that inaccessibility to technical assistance, excessive logging and legislative incentives are determinants of the extent of deforestation on a land holding. Slash-and-burn agriculture is somehow tied to land law. In the Malaysian state of Sarawak, the native customary right to land granted the natives automatic ownership of primary forest cleared for logs and agriculture before 1958 and this facilitation for land ownership has motivated slash-and-burn agriculture (Adam, 2019). In Madagascar, however, slash-and-burn agriculture is partly promoted by the absence of land titles to prevent agricultural intensification (van Vliet et al., 2012).

On a commercial scale, deforestation by slashing and burning is associated with the mainstream agricultural activities. Oil palm cultivators in Indonesia and Malaysia often resort to slash-and-burn to clear lands for oil palm cultivations and get rid of the voluminous biomass in their plantations (Tan-Soo and Pattanayak, 2019). The recent haze affecting the Indo-Malayan region was largely attributed to slash-and burn in establishing oil palm plantations (Tan-Soo and Pattanayak, 2019). In Brazil, slash-and-burn of the Amazonia makes way for soy and cattle farming which contributes immensely to country's agribusiness (Carvalho et al., 2019). 


\section{The Environmental Impacts of Slash-and-Burn Agriculture}

Slash-and-burn agriculture has received unprecedented attention especially with the occurrences of Amazon forest fire (see Figure 1 for location of wildfires in the Amazon in August 2019) and haze in the Southeast Asia. Slash-and-burn agriculture is associated with changes in soil properties, particularly the chemical properties (Thomaz, 2017). Fire is known to alter the organic contents, nutrient availability, base saturation and exchange capacity of soil (Certini, 2005). Thomaz (2013) demonstrated an increase of P, K, Mg and Ca in both the ash and the burned soil, and rainfall leached the nutrients from ash into soil, especially K. Certini (2005) reported increase of surface soil $\mathrm{pH}$ post-heating due to denaturation of organic acid and formation of alkaline ash. Excessive ash, however, could potentially impede seedling emergence and plant growth. Despite significant chemical changes, Thomaz et al. (2014) revealed limited physical changes of the soil as a result of evaporative cooling by high moisture content in the soil before burning. This suggests that high soil moisture content could limit deleterious effect of burning on physical properties of soil. While slash-and-burn agriculture under high soil moisture condition has an immediate beneficial effect on the soil, it is generally agreed that fallow period is crucial to reduce soil degradation after slashing and burning. Reducing fallow period causes higher risk of soil erosion by reducing aggregate stability besides depleting soil nutrients (Ziegler et al., 2009). With reduced fallow period, the time needed for establishment of vegetation as well as replenishment of carbon and nutrients in soil is constrained, leading to soil degradation, hence the vicious cycle of lower agricultural yield and the quest for more agricultural lands (Thomaz et al., 2014).

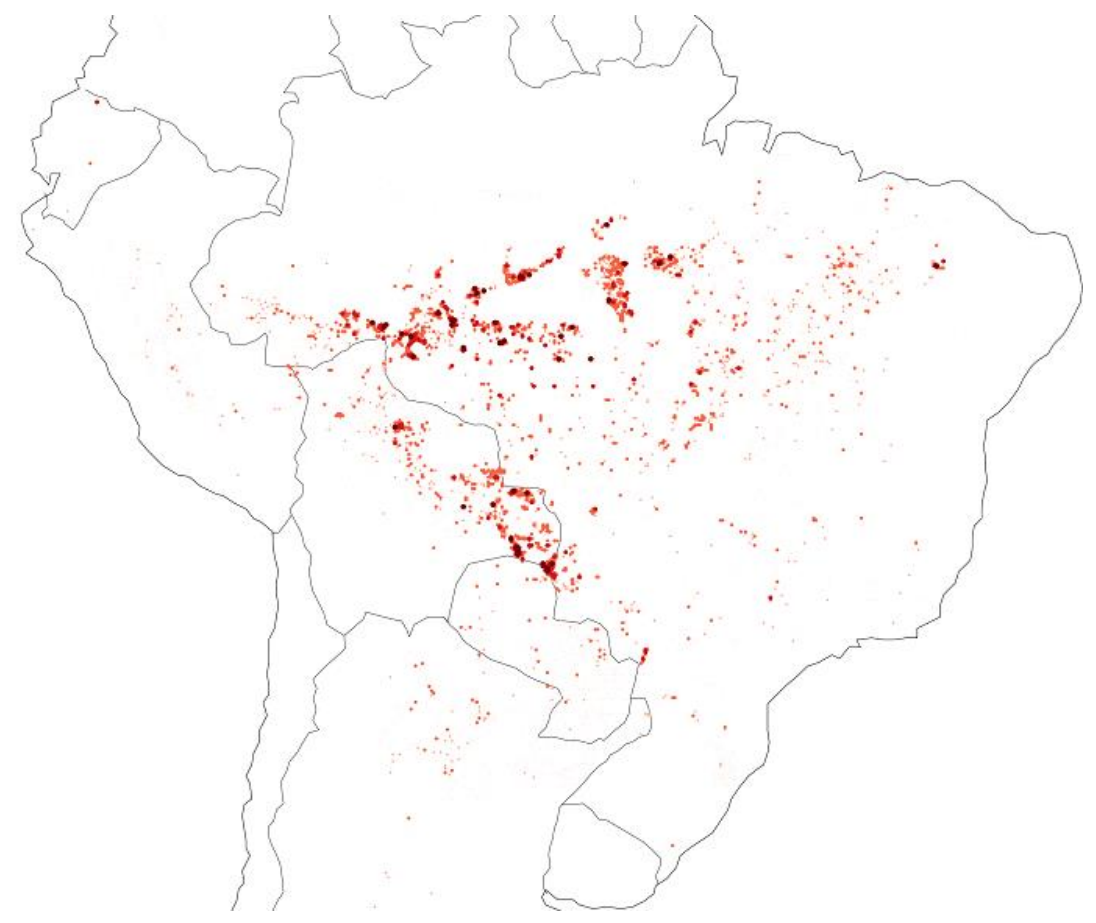

Figure 1 Map showing the locations of forest fires in the Amazonia as of August 2019. Color of the dots in the map represents the intensity of fire with darker color indicating more intense burning and more radiant energy released (Copernicus Atmosphere Monitoring Service, 2019)

In addition, slash-and-burn agriculture altered soil biota and the alteration was found to be more pronounced at sites with short fallow of approximately 8 years (Rossi et al., 2010). Rossi et al. (2010) observed species richness to be two times higher at sites with 25 -year fallow than those with 8 -year fallow characterized by highly disturbed patches. A study to investigate the effect of slash-and-burn agriculture on the soil seed bank of a Caatinga biome in Brazil showed substantial decline of soil seed bank density post-burning particularly the smaller seeds, as indicated by the lower Shanon's diversity (Mamede and de Araújo, 2008). This pointed to the potential adverse effects of slash-and-burn agriculture on plant diversity of the Caatinga biome. Frequent burning also transforms the landscape from that dominated by native woody vegetation to that characterized by fast-growing, exotic and invasive grass species with low productive and ecological value 
(Styger et al., 2007). Progressive decrease of the fallow period makes the transformation even more evident within 5-7 fallow cycles after deforestation where trees are replaced by shrubs and eventually by grasses (Styger et al., 2007). Between Balikpapan and Samarinda of Kalimantan, large area of farmlands subject to repeated slash-and-burn had turned into grasslands dominated by Imperata cylindrica (Kiyono and Hastaniah, 2000).

A study by Borges (2007) on bird biodiversity in secondary forests formed after slash-and-burn agriculture demonstrated higher species richness in old secondary forests and primary forests than young secondary forests. Bird species richness of middle-aged, old secondary and primary forests was similar. It is noteworthy that biodiversity impacts of slash-and-burn agriculture are akin to those of typical deforestation with more conspicuous recovery in deforested areas which are left undisturbed longer. Streams lined by secondary forests regenerated from past riparian deforestation by means of slashing and burning in the Malaysian Borneo showed lower abundance and diversity of benthic communities compared to those lined by primary forests though there has been signs of recovery with longer fallow (Iwata et al., 2003).

Slash-and-burn agriculture contributes to air pollution and can potentially raise public health concern particularly at regions where it is widely practiced and recurring. A study showed average ambient particulate matter hitting $191 \mu \mathrm{g} / \mathrm{m}^{3}$, average formaldehyde at $12.8 \mathrm{ppb}$ while $\mathrm{CO}$ and benzene averaging at $4.2 \mathrm{ppm}$ and $3.2 \mathrm{ppb}$ respectively during the open burning period in Rondônia, Brazil (Reinhardt et al., 2001). With the permissible limit of the Brazilian ambient PM10 exceeded and that of CO nearly exceeded, the findings highlighted the presence of significant amount of health-threatening air pollutants during agricultural burning (Reinhardtet al., 2001). Edem et al. (2012), on the other hand, revealed exceedances of the permissible limits for $\mathrm{NO}_{2}, \mathrm{SO}_{2}, \mathrm{H}_{2} \mathrm{~S}$ and $\mathrm{CO}_{2}$ in Nigeria during experimental burning. Smoke from large scale forest fires induced by slash-and-burn agriculture is a significant health risk to people living downwind, triggering respiratory problems. During the Amazon forest fires, hospitals in the affected areas received about three times the patients suffering from smoke-related health problems compared to the same period the year before (Lopes, 2019). Slash-and-burn agriculture also raises the concern of potential mercury mobility as demonstrated by Béliveau et al. (2009) that there was redistribution of mercury from fine to coarser soil particles one year after slash-and-burn, probably due to chemical competition as cation was enriched. The finding warned of potential leaching of mercury from soil during burning.

\section{Greenhouse Gases Emission from Slash-and-burn Agriculture and Its Implications on Climate Change}

Slash-and-burn agriculture releases large amount of greenhouse gases into the atmosphere. A comparison of GHGs emissions between slash-and-burn agriculture and chop-and-mulch system showed higher pyrogenic $\mathrm{CH}_{4}$ emissions and at least five times higher $\mathrm{CO}_{2}$-equivalent emissions of the former throughout the crop cycles, though chop-and-mulch increased nitric oxide and nitrous oxide emissions from soil by $50 \%$ due to higher demand for fertilizer (Davidson et al., 2008). Slash-and-burn agriculture is a major contributor of forest system carbon to the atmosphere. Overall, $25 \%$ of atmospheric $\mathrm{CO}_{2}$ emissions and as much as $10 \%$ of $\mathrm{N}_{2} \mathrm{O}$ emissions come from conversion of tropical forest and the impacts of such conversion on climate change greatly depend on the new land uses following the conversion (Palm et al., 2004). Burning of above-ground biomass is the direct cause of $\mathrm{CO}_{2}$ emissions into the atmosphere. $\mathrm{CO}_{2}$ emissions continue during cropping as the remaining above-ground biomass oxidizes and decomposes (Tinker et al., 1996).

Carried out on a small scale for subsistence farming by the indigenous, slash-and-burn agriculture does not yield major environmental concern. Small-scale slash-and-burn agriculture typically involves felling and burning of small patches of forest without extensive tilling of soil and complete removal of trees to produce a mixture of crops and forest products (Kotto-Same et al., 1997). Competitive perennials are usually planted towards the end of the cropping interval after which the lands are abandoned for natural succession for decades (Kotto-Same et al., 1997). It is the large-scale deforestation by slashing and burning to establish commercial pastures and plantations that quickly turns slash-and-burn agriculture into the culprit of environmental pollution, leading potentially to the worsening of climate change. Agricultural intensification 


\section{to Future-Proofing Climate Change}

also shortens the durations of fallow after cropping which causes soil degradation and a net loss of carbon stock as carbon does not have sufficient time to re-accumulate (Tschakert et al., 2007). With the quest for more lands for agriculture and shorter fallow which makes forest regeneration impossible, uncontrolled slashand-burn agriculture is and will become an impediment to global effort against climate change.

Wildfires of the Amazon caused by slash-and-burn practices had resulted in a noticeable upsurge of atmospheric carbon monoxide and carbon dioxide (Lopes, 2019). Increased greenhouse gases and biomassburning aerosols from the wildfires set into motion a positive climate feedback loop which further increases the vapor pressure deficit and decreases evapotranspiration, leading to lower moisture in the atmosphere, hence less precipitation (Barkhordarian et al., 2019). This sets the path for a drier Amazonia and higher risks of wildfire (Barkhordarian et al., 2019). On the other side of the world, the Indonesian forest fires, also initiated by slash-and-burn practices, emitted an estimated 708 million tonnes of carbon dioxide equivalent, which exceeded that from the Amazon wildfires (366 million tonnes carbon dioxide equivalent) by approximately two times (Jong, 2019). In terms of carbon dioxide alone, forest fires in Indonesia emitted more than 350 megatonnes as of 18 September 2019 (see Figure 2) compared to approximately 130 megatonnes of the Amazonia Legal till 26 August 2019 (see Figure 3). Having said that, the GHGs emission was still lower than the Indonesian forest fires in 2015 which churned out approximately 1385 million tonnes of carbon dioxide equivalent (Jong, 2019) (see Figure 4). The recurring forest fires point out that slash-andburn agriculture has been survived and has not been subject to sufficient regulation particularly for large-scale deforestation. Slash-and-burn agriculture on peatlands is even more environmentally damaging as peatlands contain significantly more carbon stock than other ecosystems, and burning of peatlands is a persistent problem in the Indo-Malayan region housing about $62 \%$ of the global peatlands (Tacconi and Vayda, 2006). Draining of peatlands for agricultural purposes in the region renders the peatlands more inclined to burning as the waterlogged carbon-rich peat soil dries (Tan-Soo and Pattanayak, 2019).

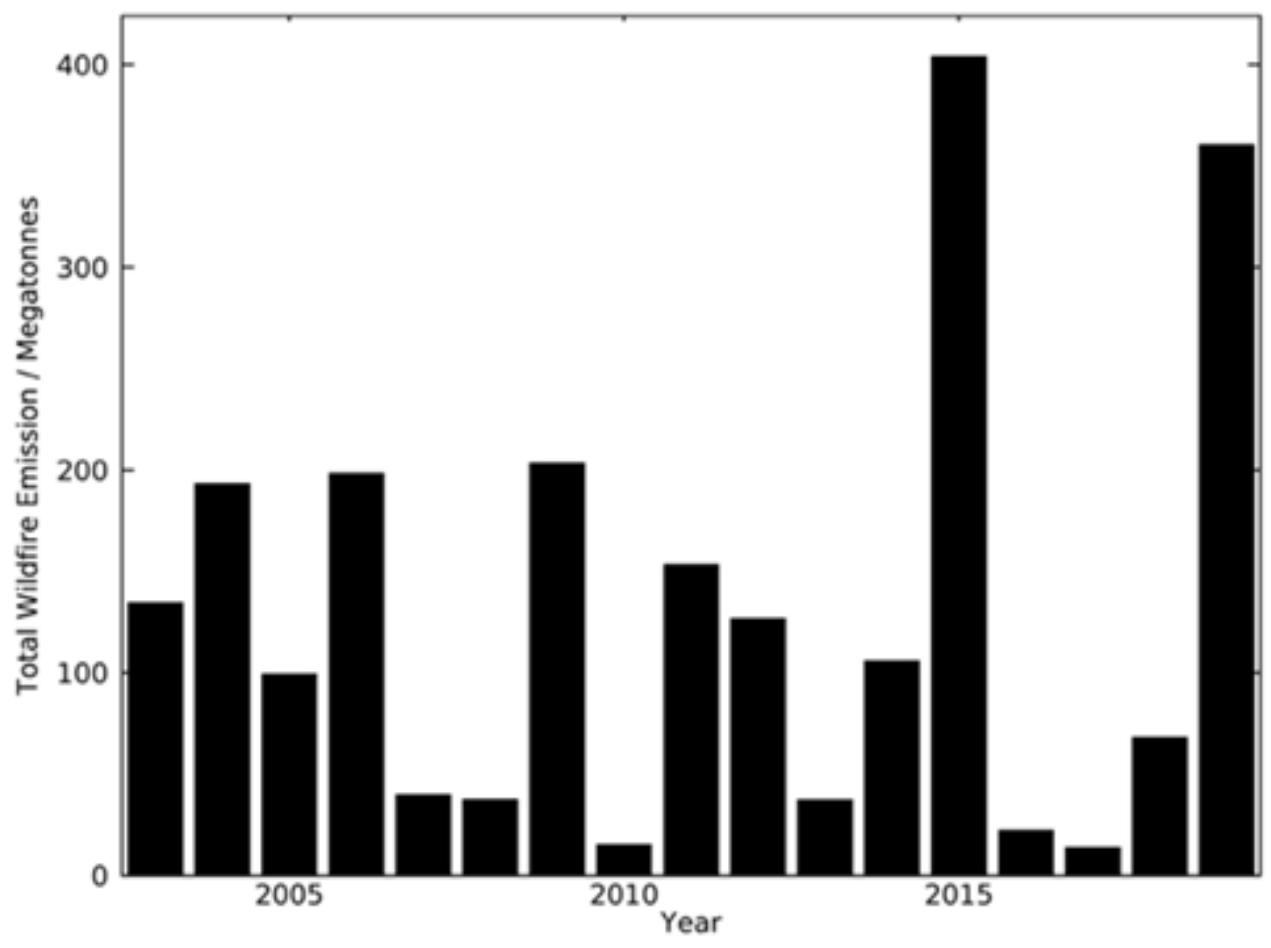

Figure $2 \mathrm{CO}_{2}$ emission of forest fires in Indonesia till September 2019 (Adopted from Copernicus Atmosphere Monitoring Service, 2019) 


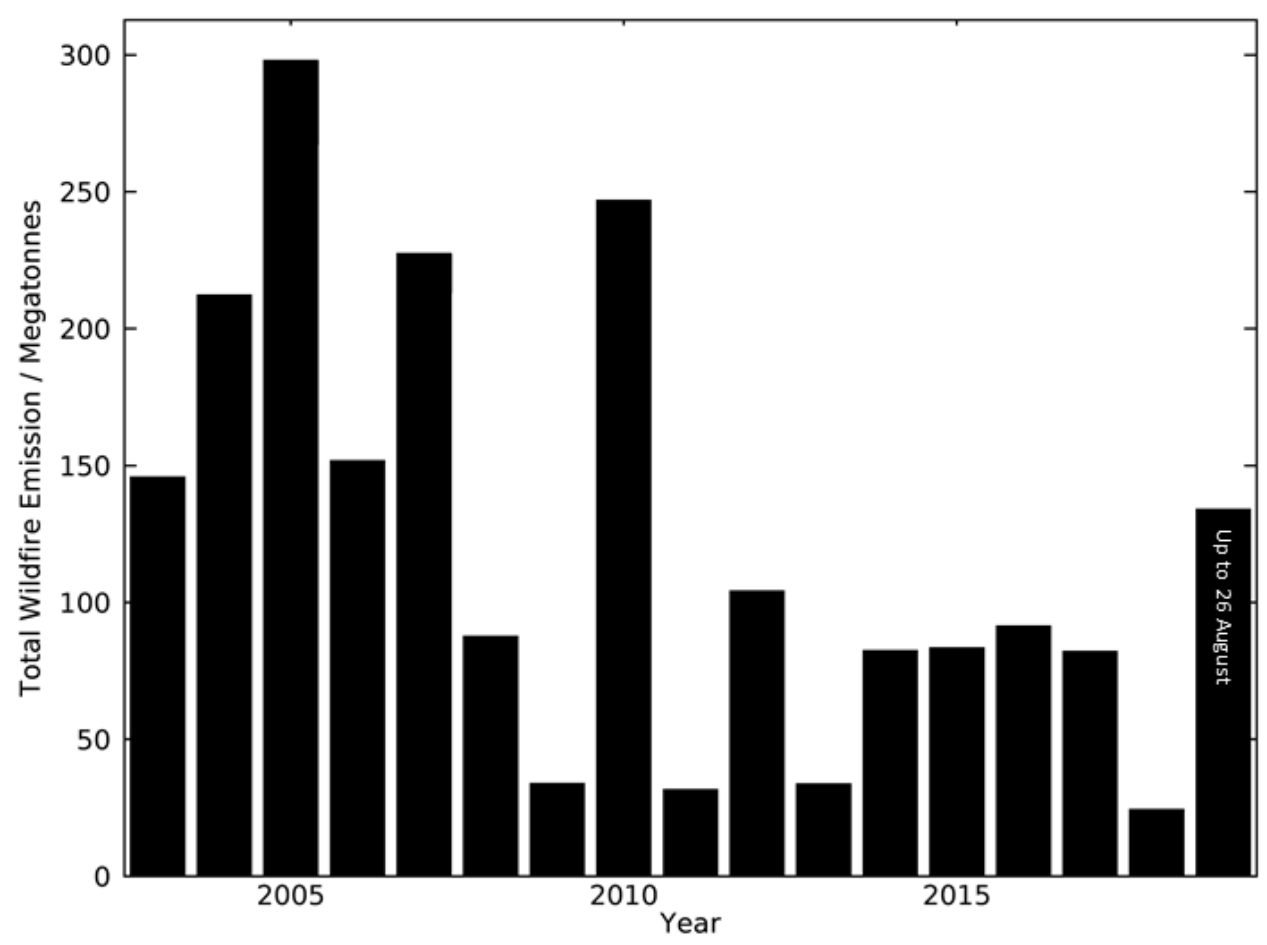

Figure $3 \mathrm{CO}_{2}$ emission of forest fires in the Amazonia Legal till 26 August 2019 (Adopted from Copernicus Atmosphere Monitoring Service, 2019)

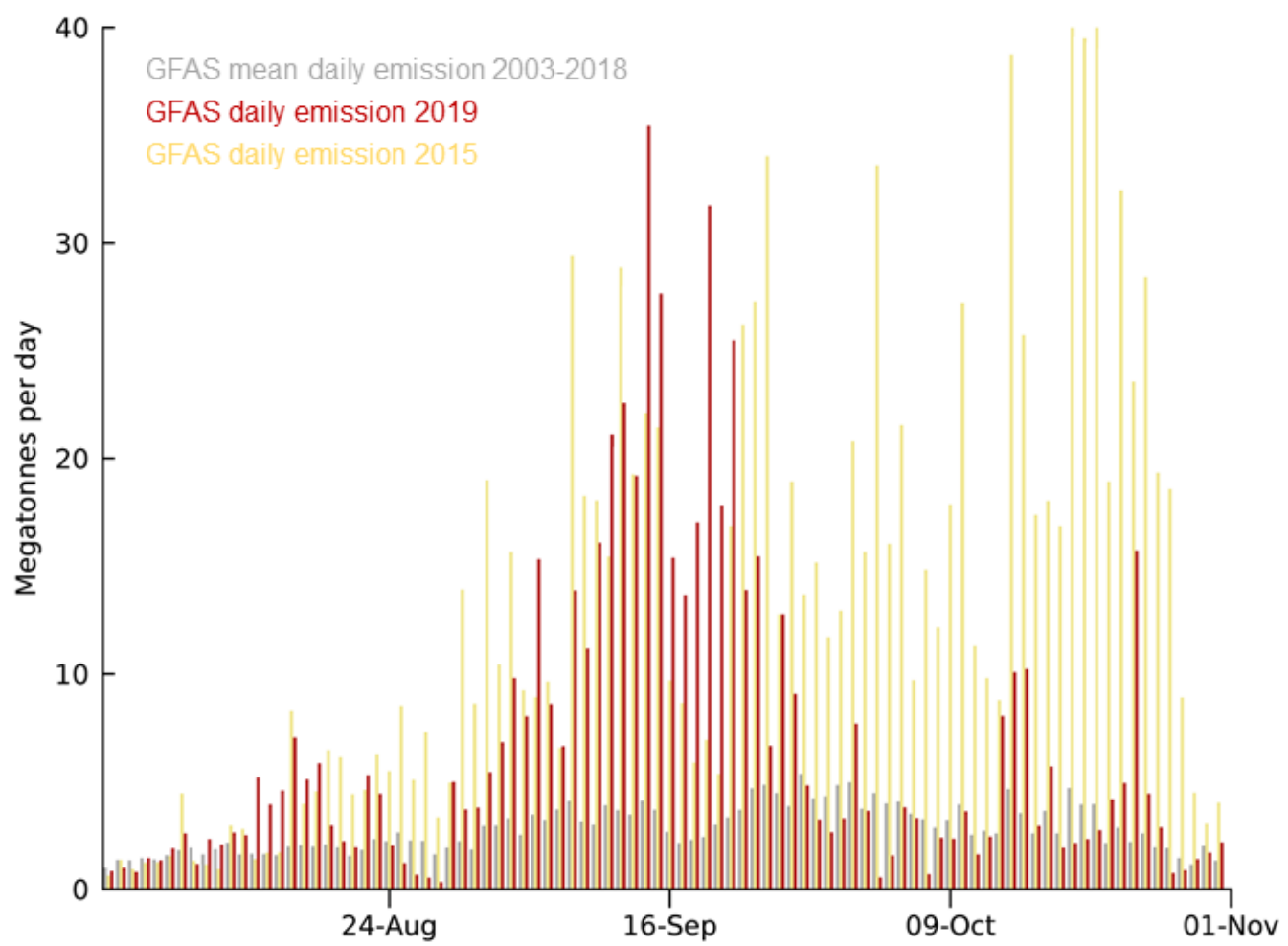

Figure 4 Daily $\mathrm{CO}_{2}$ emission of forest fires in Indonesia (GFAS - Ground Fire Acquisition System) (Adopted from Copernicus Atmosphere Monitoring Service, 2019) 


\section{Lower Atmospheric $\mathrm{CO}_{2}$ Sequestration and Its Implications on Climate Change}

Due to slash-and-burn agriculture, deforestation particularly the felling of primary forests has been reported to occur globally (Galicia et al., 2015; Lehtonen and Huttumen, 1997; Myers, 1991, Tinker et al., 1996). Deforestation not only causes the release of GHGs which had been previously discussed, but it also has considerable impact on the carbon (i.e. atmospheric $\mathrm{CO}_{2}$ ) sequestration ability of the forests. Thus, lower carbon sequestration is another important perspective which merits attention. Forests play crucial role as a huge global carbon sink due to its intrinsic ability to absorb billions of tonnes of $\mathrm{CO}_{2}$ annually (Canadell \& Raupach, 2008). Among the different types of forests, tropical humid rainforests have significant potential for carbon sequestration (Dixon et al., 1993).

Many efforts have been made in the past to reduce deforestation. Particularly, Kyoto Protocol aimed to potentially offset the carbon emissions by ensuring integrity of carbon sinks in land use, land-use change, and forestry (LULUCF) (Palm et al., 2004). Clean development mechanism (CDM) in Article 12 of the Kyoto Protocol could result in more opportunities to contribute the required compensation or institutional support to minimize deforestations or to develop land-use systems with higher carbon stocks (Palm et al., 2004). Meanwhile, a program called reducing emissions from deforestation (RED) was introduced in 2005, which was later upgraded as reducing emissions from deforestation and forest degradation (REDD) before transforming into its most current form named reducing emissions from deforestation and forest degradation which includes the sustainable management of forests, conservation of forest carbon stocks and enhancement of forest carbon stocks in developing countries (REDD+) (Gupta et al., 2016). The United Nations Framework Convention on Climate Change (UNFCCC) has suggested the approach of REDD+ mechanism which aimed at compensating the forest-rich developing nations for their efforts in minimizing forest-related GHGs emissions or carbon sequestration by using forest and land-use management approaches (Gupta et al., 2016). It is also noteworthy that there was recommendation to critically examine the past efforts undertaken to investigate the effects of pre-REDD+ projects (Caplow et al., 2011).

In order to systematically understand the effect of atmospheric $\mathrm{CO}_{2}$ sequestration, it is imperative to gain some insights into carbon dynamics of forests. The calculation of baseline measurements of carbon stocks had been investigated as above-ground carbon (AGC), below-ground carbon in root biomass (BGC) and soil organic carbon (SOC) which sum up to total ecosystem carbon (TEC) (Ziegler et al., 2012). Meanwhile, others had evaluated carbon stocks in terms of above-ground carbon stock and below-ground carbon stock (Kotto-Same et al., 1997), only above-ground biomass and below-ground biomass (which only include soil carbon but not carbon in roots) (Tschakert et al., 2007) or just aboveground biomass (d'Oliveira et al., 2011). The characterization and estimation of carbon stock is essential in the application of design and monitoring of carbon offset projects (Trexler, 1993). It is worthwhile to compare the detailed methods adopted to estimate carbon dynamics in forests. Woomer and Palm (1998) had provided estimation of the system carbon stocks in tropical forests and associated land uses derived from field activities in the tropical countries such as Brazil, Cameroon, Indonesia and Peru. They had employed allometric equation to estimate carbon stock in trees and destructive sampling to estimate carbon stock in under-storey vegetation, litter, roots and soil and suggested that ecosystems model such as CENTURY could be employed to simulate the obtained data. Meanwhile, Kotto-Same et al. (1997) evaluated carbon dynamics in 6 slash-and-burn chronosequences (namely original forest, cropland, cacao plantation, bush fallow, tree fallow and secondary forest) in the humid forests of Southern Cameroon. Nevertheless, it is to be noted that existing data gaps, inconsistencies of data quality, and the lack of standardized methods for quantifying carbon outputs were among the challenges to be resolved (Ziegler et al., 2012).

While the effect of slash-and-burn is more pronounced in tropical forests (Myers, 1991; Tinker et al., 1996), other types of forests, including temperate forests (Eckmeier et al., 2007; Galicia et al., 2015) and boreal forests (Lehtonen and Huttumen, 1997) have also been affected. Thus, it is imperative to consider the total amount of slash-and-burn in all types of forests as it will contribute to the global carbon cycle. In particular, the effect of slash-and-burn of tropical peat forest will be among the most damaging (Normile, 2019) due to 
the considerable amount of SOC present in the peat soils (Hughton \& Nassikas, 2017). Eckmeier et al. (2007) conducted experiments of anthropogenic slash-and-burn on temperate deciduous forests and discovered that although the fires in the experiments were controlled, the fires did not burn homogeneously. This confirms the highly-variable nature of the fires in forests. In view of this finding, it can be understood that slash-and-burn which is based on the utilization of fires to destroy land would have devastating effects on the primary forests. Tschakert et al. (2007) had estimated that the carbon sequestration rates amounted to 0.3-3.7 t C ha ${ }^{-1} \mathrm{y}^{-1}$ based on both the biomass and soil carbon data, for slash-and burn agriculture in eastern Panama.

The effects of slash-and-burn on the carbon stocks in aboveground biomass had been studied by some researchers (d'Oliveira et al., 2011; Kiyono et al., 2007). d'Oliveira et al. (2011) had estimated the aboveground biomass after slash-and-burn of the dry primary forests in the southern Brazilian Amazon. They had investigated four plots and found that due to higher fire severity, one of the plots had demonstrated lowered biomass accumulation, thus also confirming the ill-effects of the high-intensity fire in slash-and-burn. Kiyono et al. (2007) studied slash-and-burn in northern Lao People's Democratic Republic, whereby they had determined the relationship between the fallow period and fallow-period-average carbon stocks in the three carbon stocks of bamboo-dominated hilly areas of the Luang Prabang Province. They revealed that sufficient fallow time period for slash-and-burn agriculture is crucial in terms of maintaining carbon stocks, whereby increasing the fallow period from 2 to 5 years had enhanced fallow-period-average carbon stock from 14.2 to 25.1 $\mathrm{Mg} \mathrm{C} \mathrm{ha}{ }^{-1}$.

Meanwhile, some researchers had investigated the effects of slash-and-burn agriculture on the soil organic carbon (SOC) (Bahr et al., 2014; Ohstuka et al., 2007; Panosso et al., 2009; Rumpel et al., 2006; Vashum \& Jayakumar, 2016). Bahr et al. (2014) found that forest conversion by slash-and-burn reduced SOC stocks totaling between $14 \%$ and $19 \%$ in all three land uses (namely pasture, perennial plantation cropping, and annual cropping). Ohtsuka et al. (2007) evaluated the effect of fire on soil $\mathrm{CO}_{2}$ efflux, nutrient dynamics and microbial biomass at two slash-and-burn sites (which were later transformed into an agroforestry system of red turnips (Brassica rapa L. var. glabra Kitam) and Japanese cedar (Cryptomeria japonica D. Don.) in central Japan. They discovered significant increase in soil $\mathrm{CO}_{2}$ after slash-and-burn which could be attributed to fire-induced high microbial activity. They further found that significant release of $\mathrm{C}$ was ascribed to both combustion of litter and decomposition of soil organic matter (SOM). Panosso et al. (2009) investigated the soil carbon dynamics in lands planted with sugarcane in southern Brazil under two sugarcane management systems, namely green system with mechanized harvesting, and slash-and-burn. Their findings revealed that the mean soil $\mathrm{CO}_{2}$ emission was $39 \%$ higher in the slash-and-burn system as compared to the green system, with the emission rates of $2.87 \mu \mathrm{mol} \mathrm{m} \mathrm{m}^{-2} \mathrm{~s}^{-1}$ and $2.06 \mu \mathrm{mol} \mathrm{m} \mathrm{m}^{-2} \mathrm{~s}^{-1}$, respectively. Rumpel et al. (2006) conducted a study on the sloping soils in Northern Laos to quantify the amount of black carbon (BC) which was formed after slash-and-burn agriculture and its effects on the chemical and stable isotope composition of SOM at different elevations of the slopes (bottom of the slope, midslope, and top of the slope). They found that the highest $\mathrm{BC}$ stocks were attributed to intensive slash-and-burn activity and that it could significantly affect the SOC content. Vashum and Jayakumar (2016) investigated the effect of slash-and-burn agriculture in India, and they found that slash-and-burn had significantly reduced the SOC content of the top and bottom layers of the sampled soil, though it did not reach a level that would not permit another round of agriculture. Nevertheless, they recommended that further studies are required to determine crop yields in subsequent cycles of agriculture. Meanwhile, on the same note, Izac (1997) had provided some of the major advantages of sustainable soil carbon management at different levels, as shown in Figure 5. 

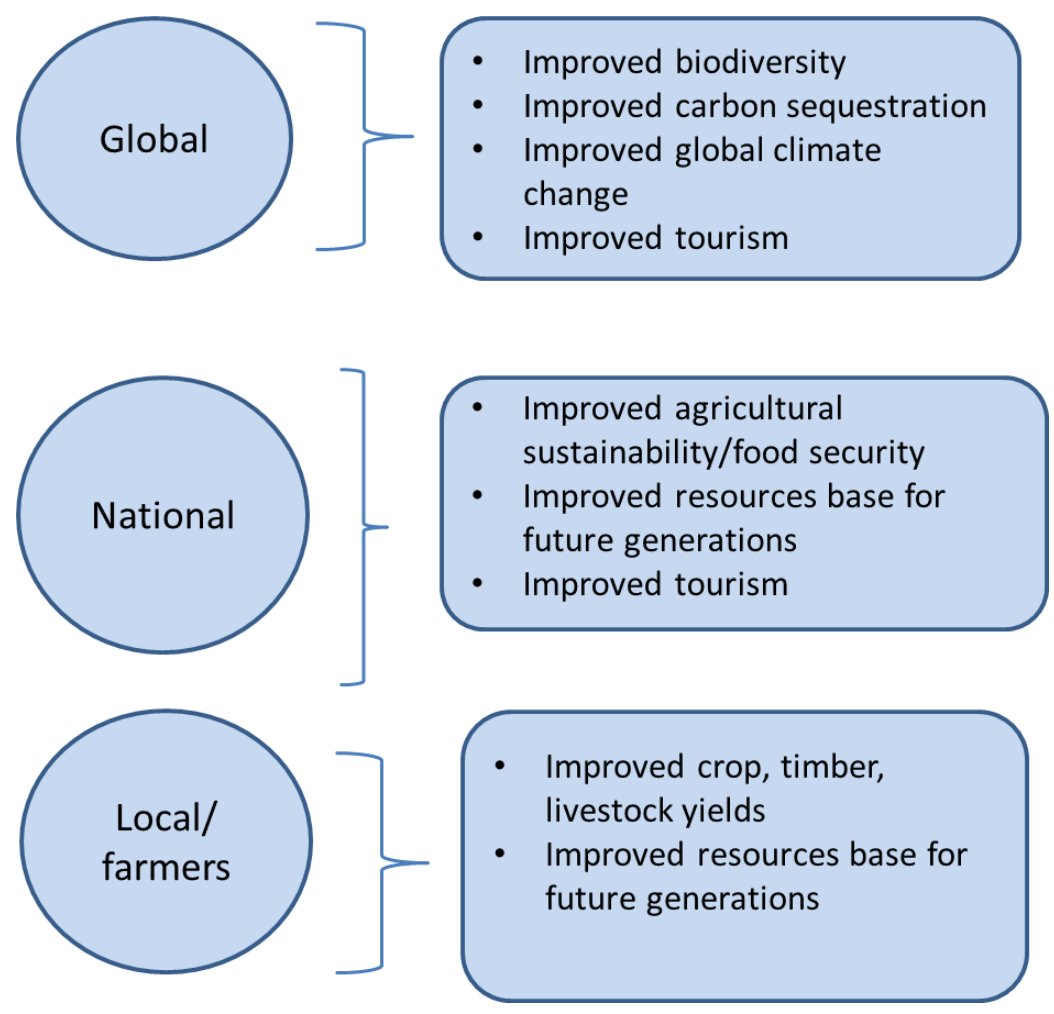

Figure 5 The main advantages of managing soil carbon sustainably at different levels (Adopted from Izac, 1997)

\section{Recommendations for Alternative Practices}

In general, the United Nations Conference on the Environment and Development (UNCED) found tropical deforestation to be a global environmental concern, and that slash-and-burn agriculture was in particular, a specific concern (Kotto-Same et al., 1997). Consequently, the global environmental facility (GEF) had awarded an international consortium of research and development the required funding to study alternatives to slash-and-burn agriculture (Kotto-Same et al., 1997). The creation of alternatives-to-slash-and-burn (ASB) program was aimed to tackle the implications of slash-and-burn agriculture in the humid tropical regions in the world (Brady, 1996). Brady (1996) had revealed some insights on alternatives to slash-and-burn (ASB), which were both economically and socially acceptable, and provided a conceptual framework for the development of alternatives to slash-and-burn program, as shown in Figure 6. Meanwhile, Tomich et al. (1998) proposed the development of agriculture should be simultaneously occurring with conservation of rainforests through designing best-bet alternatives to slash-and-burn. They had focused their research particularly on the applications to Brazil and Indonesia. Palm et al. (2004) had presented case studies from ASB, and revealed how it could be related to the mitigation of GHGs emissions in the humid tropical locations in the world. 


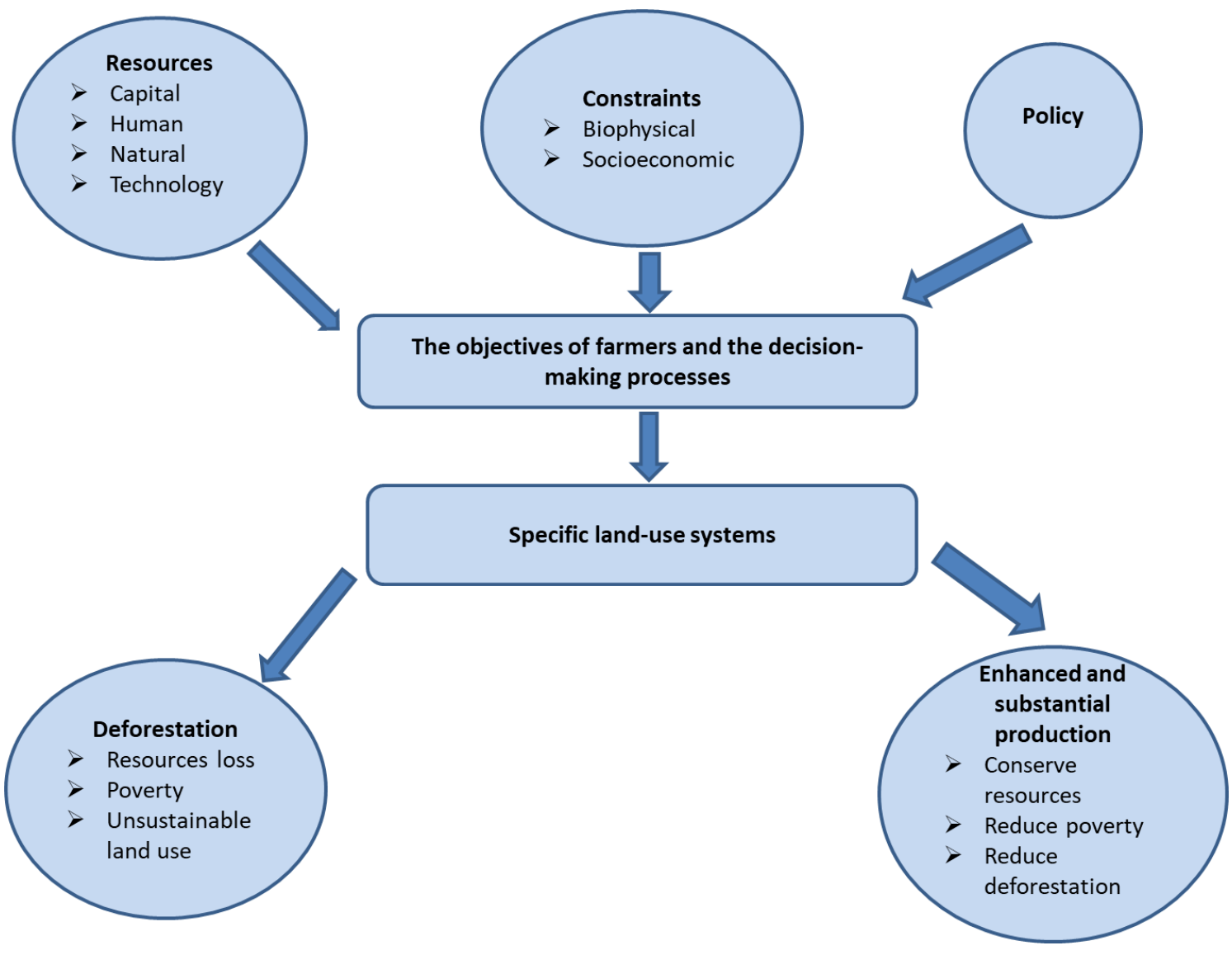

Figure 6 Schematic illustrating the conceptual framework derived from GEF project for the development of the alternatives to slash-and-burn (Brady, 1996)

In general, there are two main methods for alternatives to slash-and-burn, namely land preparation, and landuse systems. In terms of land preparation, a few of its approaches include addition of cover on top of the soil/mulching (Eastmond \& Faust, 2006; Kato et al., 1999; Mburu et al., 2007), improved forest conversion (Kotto-Same et al., 1997), mechanized land preparation (Denich et al. 2004, Mburu et al., 2007; Panosso et al., 2009; Reichert et al., 2014), and simple slash-and-char system (Liang et al., 2018). Eastmond and Faust (2006) had mentioned that according to SEMARNAT, the federal environmental protection agency of Mexico, the application of fire in agriculture can primarily yield conflagration. They introduced green cover crop to the traditional farmers in Yucatan peninsula and Calakmul Biosphere Reserve, Mexico. Kato et al. (1999) demonstrated that while the fire-free alternatives to slash-to-burn, namely either mulching or inclusion of the slashed and chopped vegetation/biomass resulted in reduced rice and cowpea yields, the yields of the cassava was not significantly affected. This confirms that the fire-free agriculture can be applicable to some crops, and this may result in the reduced adoption of slash-and-burn practices in agriculture. Mburu et al. (2007) revealed that mechanical mulching technology in Bragantina area of Brazil was generally profitable financially and economically. However, in order to make it a feasible alternative to the slash-and-burn practices in eastern Amazon, there are a few criteria to be met, one of which is abandonment of the single cropping cycle and the selection of profitable crop combinations for agriculture. Kotto-Same et al. (1997) had suggested that forest conversion may be improved through improved land preparation, i.e. to adopt more conservation-oriented land preparation which could be consisted of safeguarding economically essential tree species, contour felling and management of mound-based soil fertility.

Denich et al. (2004) evaluated the effects of mechanized land preparation on smallholders in eastern Amazonia and highlighted that the utilization of machines for harvesting fallowed vegetation and chopping it could eliminate the usage of fire for land clearing, manpower for labor, and increase the agriculture productivity. Mburu et al. (2007) investigated mechanical mulching technology in Brazil. Panosso et al. 
(2009) compared the mechanized harvesting method with slash-and-burn in Sao Bento farm, in Sao Paulo, Brazil. Reichert et al. (2014) examined the changes in the mechanical characteristics and hydrological properties (i.e. water retention) of soils which were subjected to different tillage systems of secondary vegetation after a fallow period of 10 years in eastern Amazon, Brazil. Liang et al. (2018) recently introduced a simple slash-and-char system (as opposed to other sophisticated slash-and-char systems) which could be easily adopted by smallholder farmers in the developing countries. They revealed that their system could achieve a conversion of $30.7 \%$ of initial carbon content in rice straw into biochar, as compared to only $3.95 \%$ stored in the ash produced through open burning.

Meanwhile, it is noteworthy that there are some agricultural practices such as the no tillage agriculture (Powlson et al., 2014) or reduced tillage agriculture (D'Haene et al., 2009), which had been studied in terms of SOC content. Powlson et al. (2014) suggested that no-till agriculture practice had only limited potential in terms of soil carbon sequestration but it still can be promoted as a strategy to adapt to climate change but not for mitigating climate change. D'Haene et al. (2009) demonstrated that after a few years of adopting reduced tillage on the agriculture silt loam soils, the SOC content could increase in the surface layer, but the increment did not occur in the whole $0-60 \mathrm{~cm}$ layer of soil profile. Thus, it may be concluded that the effect of tillage in agriculture is not likely to be the main factor enhancing SOC.

In terms of land-use systems, it can generally be categorized into five approaches, namely (i) alternative agrosystems/ plantation of suitable crops (Aguilar-Jimenez et al., 2013; Kotto-Same et al., 1997), (ii) agroforestry (Grogan et al., 2012; Kotto-Same et al., 1997; Lasco et al., 2014; Martorano et al., 2016; Moura et al., 2013; Tremblay et al., 2015; Unruh et al., 1993; Verchot et al., 2007), (iii) cultivated pastureland (Strassburg et al., 2014), (iv) integrated system of crop-livestock-forests (Gil et al., 2015), and (v) other agricultural land technologies (Grogan et al., 2012). Aguilar-Jimenez et al. (2013) had compared the analysis of environmental parameters in a traditional agroecosystem (namely slash, fell and burn) and alternative method (namely medication of the sowing density with subsequent rotation of Mucuna deeringiana) for agrosystems of maize in Chiapas, Mexico. The burning period was from spring to summer while the no burning period was from autumn to winter. The findings from alternative agrosystem were favorable, for example the modification of sowing density yielded maize yield of $3.1 \mathrm{t} / \mathrm{ha}$, as compared to $1.8 \mathrm{t} / \mathrm{ha}$ in the traditional slash-and-burn practice. Kotto-Same et al. (1997) had indicated that in terms of suitable crops, cassava had been reported to be a suitable crop due to its ease of growing. They suggested cassava due to its efficiency in exploiting scarce nutrient and producing huge industrial yield outputs. Meanwhile, it has been revealed that the type of crops planted may have an impact on the release of SOC and soil nitrogen (Anaya and Huber-Sannwald; 2015; McLauchlan, 2006). Anaya and Huber-Sannwald (2015) had investigated the long-term SOC and soil nitrogen dynamics due to the land-use change from forest to indigenous sugarcane agriculture in the tropical region of East Mexico. McLauchlan (2006) had employed a 40-year chronosequence of 62 former agricultural lands in western Minnesota, USA to evaluate the effects of clay concentration on the soil carbon and nitrogen stocks after the abandonment of the agricultural lands.

Agroforestry has a high potential of being an alternative, due to both the sustainability factors as well as its ability to adapt to climate change (Verchot et al., 2007). It has also been mentioned that through land-use change, development of tree-based system on croplands or grasslands could potentially act as the largest carbon sink globally (Watson et al., 2000). In addition, the climate change adaptation and mitigation potential demonstrated by agroforestry systems is shown in Figure 7 (Lasco et al. (2014). 


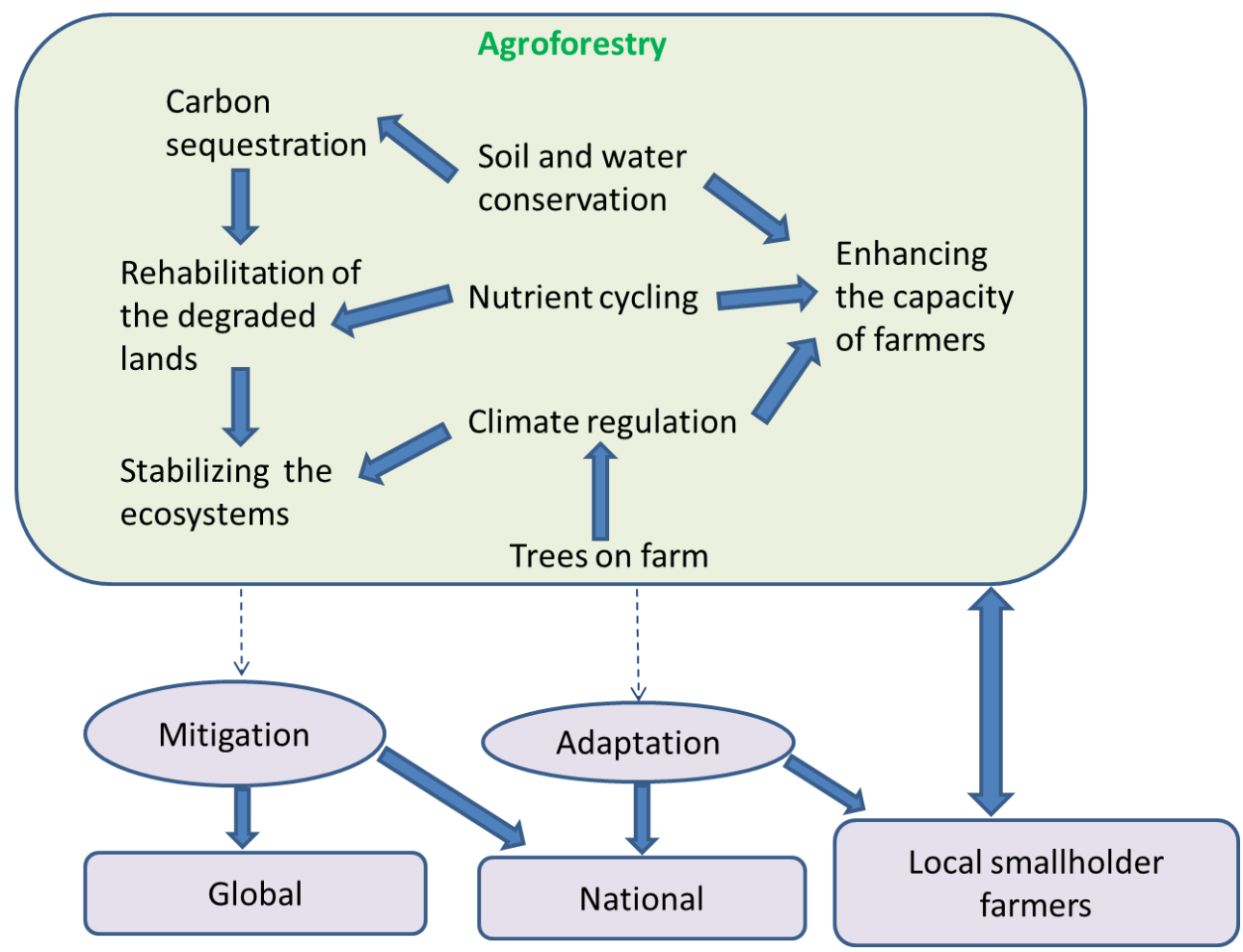

Figure 7 Schematic illustrating the potential of agroforestry systems as adaptation to and mitigation of climate change (Lasco et al., 2014)

Grogan et al. (2012) had suggested agroforestry to be conducted using anti-erosional plants on the steep slopes in the state of Mizoram, northeast India. Kotto-Same et al. (1997) had suggested that stratification of agroforestry could be potential alternative to slash-and-burn. As a system which involves the cultivation of a complex combination of trees, shrubs and herbaceous crops, agroforestry can cater to both the demands of local/domestic and market scales. Lasco et al. (2014) had recommended agroforestry system due to its favorable synergies between adaptation and mitigation of climate change and that it is particularly beneficial for smallholder farmers. Among the advantages of agroforestry include improved water usage, enhanced microclimate, increased soil productivity and nutrient usage, pest control and minimization of diseases, enhanced crop yield, increased income and carbon sequestration. Martorano et al. (2016) revealed their findings of combining the soybean and parica (Glycine max L. and Chizolobium amazonicum) in the Para state of Brazil, whereby the soybean production was $3.4 \mathrm{t} \mathrm{ha}^{-1}$, while the parica had mutually benefited from soybean plantation during the first year, with superior development in height of $3.26 \mathrm{~m}$ and average diameter of $3.85 \mathrm{~cm}$. Moura et al. (2013) had recommended alley cropping (a form of agroforestry) as a potential alternative to slash-of-burn practices in the humid tropical region, due to production of huge amount of residues on the surfaces of the soil and enhanced long-term crop productivity.

Tremblay et al. (2015) had shown the short-and medium-term profitability of two agroforestry systems experimented in Tapajo region in Brazil to be favorable, where the net present value (NPV) analysis showed that the total implementation and operating costs could be recovered in 20 years. Unruh et al. (1993) had estimated that agroforestry could offset carbon emissions from Africa for 20-125 years through three approaches, namely the carbon accumulation in wood and soil, minimization of deforestation of neighboring forests, and replacement of fossil fuels by using fuelwood. Verchot et al. (2007) had investigated the mitigation ability of agroforestry in the humid and sub-humid tropical regions (i.e. reducing the atmospheric GHGs) and further suggested that agroforestry could contribute to climate change adaptation, especially for the smallholder farmers. Strassburg et al. (2014) had examined 115 million hectares of area in Brazil and they found that the improved usage of cultivated pastureland could potentially increase the productivity by $49-52 \%$ of the current potential and this would be adequate to meet the demands for food and energy until 2040, thus potentially mitigating up to $14.3 \mathrm{Gt}$ of $\mathrm{CO}_{2}$ eq. Gil et al. (2015) had discussed on the practice and 
implementation of integrated system in Mato Grosso, Brazil. They had considered the following four types of integrated system, namely iCL (crop-livestock systems), iLF (livestock-forestry systems), iCF (crop-forestry systems), and iCLF (crop-livestock-forestry systems). Their findings showed that integrated system was present in more than 40 out of a total of 141 municipalities in the Mato Grasso region, and iCL method was the most common integrated system at $89 \%$. Meanwhile, Grogan et al. (2012) had also suggested some other agricultural technologies such as inclusion of nitrogen-fixing shrub hedgerows, slope terracing and bamboo forest harvesting in the steep slopes of Mizoram, India.

Finally, on the practical side, it is also important to ensure the satisfactory acceptance and large-scale adoption of alternatives-to-slash-and-burn among the smallholder farmers. There are many challenges such as social-cultural, economic, environmental, institutional, policy/legal and scientific/technological which need to be taken into account (Eastmond \& Faust, 2006; Smith et al., 1999; Strassburg et al., 2014). However, with the over-arching goal of safeguarding the environment and all stakeholders from the catastrophic impacts of climate change, these challenges should instead be viewed as opportunities to find sustainable solutions.

In view of the multitude of agricultural practices which can potentially substitute slash-and-burn, and the drivers of slash-and-burn comprising mainly to optimize farm production in a short duration with low operational cost, the lack of manpower and machinery as well as the indifference towards its environmental consequences, the practical approaches would be to continuously educate farmers on the negative consequences of slash-and-burn while introducing them new cost-effective farming techniques particularly the low-cost slash-and char involving the construction of simple earthen pits at farms for drying and charring of the felled vegetation (Braga \& Martensen, 2017; Liang et al., 2018). The biochar produced is better than ash from biomass-burning in fertilizing soil (Liang et al., 2018). Government incentives and intervention to assist the farmers in adopting the new agricultural practices is crucial, particularly agroforestry. In Malaysia, the Sarawak Forest Department pioneered an agroforestry project of helping the indigenous communities in planting Aquilaria microcarpa on lands which otherwise would have been slashed and burned for farming of mainstream crops such as oil palms (Borneo Post Online, 2014). Aquilaria microcarpa (agarwood) could produce highly valued resin and this project was successful in raising the income of the communities (Borneo Post Online, 2014).

\section{Conclusion}

It needs to be reiterated that slash-and-burn agricultural practices in recent decades are different from the traditional slash-and-burn agricultural methods whereby the current slash-and-burn agriculture particularly does not allow sufficient fallow time for regeneration of the soil nutrients which thus limits the growth of secondary forests and that it is now primarily adopted in the direction towards large-scale commercialization. Of late, there are more incidences of slash-and-burn agriculture which are occurring in tropical regions of Southeast Asia, Africa and the Amazonia. The drivers for slash-and-burn agriculture have been identified and they encompass the need for the resource-poor smallholder farmers to make a living (due to limited alternatives), unreceptive to new changes due to adherence to age-old practice of slash-and-burn, economic factors which include commercialization of cash-crops and/or profitable plantations, and demographic factors in certain locations in some countries. The environmental effects of slash-and-burn agriculture include alteration of the soil properties and biota, damage to plant diversity, threat to animal biodiversity in forests and severe air pollution. The impacts of slash-and-burn on climate change can be categorized into two main parts, namely GHGs emission and reduced atmospheric $\mathrm{CO}_{2}$ sequestration. Among the GHGs, emissions of $\mathrm{CO}_{2}$ and $\mathrm{CH}_{4}$ are generally the most damaging to the environment and living beings. With increasing GHGs emissions, hence atmospheric temperatures, global warming is likely to be more serious in the near future. The lowered carbon sequestration will also be a barrier to the mitigation and adaptation of climate change, and more efforts/policies must be made to ensure the conversion of atmospheric $\mathrm{CO}_{2}$ to above-ground carbon (e.g. trees, deadwoods, and litters) and below-ground carbon (e.g. in the roots of trees and as soil organic carbon). Thus, it is now a high time to seriously look into the various alternatives which are proven effective to slash-and-burn agriculture, which generally include land preparation and land-use systems. Appropriate 
policies must be carefully planned and implemented at national, regional and international levels, in order for the desired effects to materialize. Specifically targeting at the drivers of slash-and-burn, a multi-pronged approach comprising low-cost slash-and-char and agroforestry with government's incentives and intervention is deemed feasible. In conclusion, the episodes of slash-and-burn agriculture may be thought of as a cycle of interaction of the fires, forests, farmers, food and finance, whereby farmers utilize fire-based agricultural method to destroy forests to ensure food security and financial gain. While it is crucial to ensure current and future food security, it should be done in a manner that would not result in adverse consequences of slashand-burn agriculture, especially with regards to climate change. Thus, in order to future-proof global climate change, the widespread adoption of slash-and-burn agriculture is recommended to be significantly reduced. As an alternative, other sustainable agricultural practices which have minimal ill-effects on climate change should be immediately advocated.

\section{Acknowledgements}

The Research Conference Fund (RCF) from Xi'an Jiaotong-Liverpool University, China is gratefully acknowledged.

\section{References}

Adam, F. J., 2019, Native Customary Rights Over Land in Sarawak. Journal of Malaysian and Comparative Law; Vol 25 (1998): Journal of Malaysian and Comparative Law, Date of access: 18/01/2020. https://ejournal.um.edu.my/index.php/JMCL/article/view/16140.

Aguilar-Jiménez, C. E., Tolón-Becerra, A., and Lastra-Bravo, X. B., 2013, Traditional agroecosystems vs. alternative agroecosystems in maize in Chiapas Mexico. The Journal of Animal \& Plant Sciences, 23, 633-646.

Anaya, C. A., and Huber-Sannwald, E., 2015, Long-term soil organic carbon and nitrogen dynamics after conversion of tropical forest to traditional sugarcane agriculture in East Mexico. Soil and Tillage Research, 147, 20-29.

Bahr, E., Zaragocin, D. C., and Makeschin, F., 2014, Soil nutrient stock dynamics and land-use management of annuals, perennials and pastures after slash-and-burn in the Southern Ecuadorian Andes. Agriculture, Ecosystems \& Environment, 188, 275-288

Barkhordarian, A., Saatch, S. S., Behrangi, A., Loikith, P. C., and Mechoso, C. R., 2019, A recent systematic increase in vapor pressure deficit over tropical South America. Scientific Reports, 9(1), 15331. doi: 10.1038/s41598-019-51857-8.

Béliveau, A., Lucotte, M., Davidson, R., do Canto Lopes, L. O., Paquet, S., 2009, Early Hg mobility in cultivated tropical soils one year after slash-and-burn of the primary forest, in the Brazilian Amazon. Science of The Total Environment, 407(15), 4480-4489. doi: https://doi.org/10.1016/j.scitotenv.2009.04.012.

Borges, S. H., 2007, Bird assemblages in secondary forests developing after slash-and-burn agriculture in the Brazilian Amazon. Journal of Tropical Ecology, 23(4), 469-477. doi: DOI: 10.1017/S0266467407004105.

Borneo Post Online, 2014, Highly valued wood for rural community, Date of access 16/07/2020. https://www.theborneopost.com/2014/09/28/highly-valued-wood-for-rural-community/

Brady, N. C., 1996, Alternatives to slash-and-burn: a global imperative. Agriculture, Ecosystems \& Environment, 58(1), 3-11.

Braga, A. C. R., and Martensen, A. C., 2017, Smallholders: Drivers or targets of Amazonian Deforestation. Human Geography, 10(1), 67-69.

Canadell, J. G., and Raupach, M. R., 2008, Managing forests for climate change mitigation. Science, 320(5882), 1456-1457.

Caplow, S., Jagger, P., Lawlor, K., and Sills, E., 2011, Evaluating land use and livelihood impacts of early forest carbon projects: Lessons for learning about REDD+. Environmental Science \& Policy, 14(2), 152-167.

Carvalho, W. D., Mustin, K., Hilário, R. R., Vasconcelos, I. M., Eilers, V., and Fearnside, P. M., 2019, Deforestation control in the Brazilian Amazon: A conservation struggle being lost as agreements and regulations are subverted and bypassed. Perspectives in Ecology and Conservation, 17(3), 122-130. doi: https://doi.org/10.1016/j.pecon.2019.06.002. 
Certini, G., 2005, Effects of fire on properties of forest soils: a review. Oecologia, 143(1), 1-10. doi: $10.1007 / \mathrm{s} 00442-004-1788-8$.

Christoff, P., 2016, The promissory note: COP 21 and the Paris Climate Agreement. Environmental Politics, 25(5), 765-787. doi: 10.1080/09644016.2016.1191818.

Copernicus Atmosphere Monitoring Service, 2019, Emissions and surface fluxes, Date of access: 20/01/20. https://atmosphere.copernicus.eu/emissions-and-surface-fluxes

Cornell, J., 2011, Slash and burn, The Encyclopedia of Earth, Date of access: 19/01/2020. http://editors.eol.org/eoearth/wiki/Slash_and_burn.

D'Haene, K., Sleutel, S., De Neve, S., Gabriels, D., and Hofman, G., 2009, The effect of reduced tillage agriculture on carbon dynamics in silt loam soils. Nutrient Cycling in Agroecosystems, 84(3), 249-265.

d'Oliveira, M. V. N., Alvarado, E. C., Santos, J. C., and Carvalho Jr, J. A., 2011, Forest natural regeneration and biomass production after slash and burn in a seasonally dry forest in the Southern Brazilian Amazon. Forest Ecology and Management, 261(9), 1490-1498.

Davidson, E. A., De Abreu Sá, T. D., Carvalho, C. J. R., De Oliveira Figueiredo, R., Kato, M. S. A., Kato, O. R., and Ishida, R. Y., 2008, An integrated greenhouse gas assessment of an alternative to slash-and-burn agriculture in eastern Amazonia. Global Change Biology, 14(5), 998-1007. doi: 10.1111/j.13652486.2008.01542.x.

Denich, M., Vielhauer, K., Kato, M. D. A., Block, A., Kato, O. R., de Abreu Sá, T. D., Lucke, W., and Vlek, P. L., 2004, Mechanized land preparation in forest-based fallow systems: The experience from Eastern Amazonia. Agroforestry Systems, 61(1-3), 91-106.

Dixon, R. K., Andrasko, K. J., Sussman, F. G., Lavinson, M. A., Trexler, M. C., and Vinson, T. S., 1993, Forest sector carbon offset projects: near-term opportunities to mitigate greenhouse gas emissions. In Terrestrial Biospheric Carbon Fluxes Quantification of Sinks and Sources of $\mathrm{CO}_{2}$, (Dordrecht, Netherlands: Springer), pp. 561-577.

Eastmond, A., and Faust, B., 2006, Farmers, fires, and forests: a green alternative to shifting cultivation for conservation of the Maya forest? Landscape and Urban Planning, 74(3-4), 267-284.

Eckmeier, E., Rösch, M., Ehrmann, O., Schmidt, M. W., Schier, W., and Gerlach, R., 2007, Conversion of biomass to charcoal and the carbon mass balance from a slash-and-burn experiment in a temperate deciduous forest. The Holocene, 17(4), 539-542.

Edem, I. D., Opara-Nadi, O. A., and Ijah, C. J., 2012. Effects of biomass burning on soil properties and air quality under slash-and-burn agriculture. Agriculture, 52, 11555-11564.

Galicia, L., Gómez-Mendoza, L., and Magaña, V., 2015, Climate change impacts and adaptation strategies in temperate forests in Central Mexico: a participatory approach. Mitigation and Adaptation Strategies for Global Change, 20(1), 21-42.

Gay-des-Combes, J. M., Robroek, B. J. M., Hervé, D., Guillaume, T., Pistocchi, C., Mills, R. T. E., and Buttler, A., 2017, Slash-and-burn agriculture and tropical cyclone activity in Madagascar: Implication for soil fertility dynamics and corn performance. Agriculture, Ecosystems \& Environment, 239, 207-218. doi: https://doi.org/10.1016/j.agee.2017.01.010.

Gil, J., Siebold, M., and Berger, T., 2015, Adoption and development of integrated crop-livestock-forestry systems in Mato Grosso, Brazil. Agriculture, Ecosystems \& Environment, 199, 394-406.

Grogan, P., Lalnunmawia, F., and Tripathi, S. K., 2012, Shifting cultivation in steeply sloped regions: a review of management options and research priorities for Mizoram state, Northeast India. Agroforestry Systems, 84(2), 163-177. doi: 10.1007/s10457-011-9469-1.

Gupta, A., Pistorius, T., and Vijge, M. J., 2016, Managing fragmentation in global environmental governance: the REDD+ Partnership as bridge organization. International Environmental Agreements: Politics, Law and Economics, 16(3), 355-374.

Houghton, R. A., and Nassikas, A. A., 2017, Global and regional fluxes of carbon from land use and land cover change 1850-2015. Global Biogeochemical Cycles, 31(3), 456-472.

Iwata, T., Nakano, S., and Inoue, M., 2003, Impacts of past riparian deforestation on stream communities in a tropical rain forest in Borneo. Ecological Applications, 13(2), 461-473. doi: 10.1890/10510761(2003)013[0461:IOPRDO]2.0.CO;2. 
Izac, A. M., 1997, Developing policies for soil carbon management in tropical regions. Geoderma, 79(1-4), 261276.

Jong, N. H., 2019, Indonesia fires emitted double the carbon of Amazon fires, research shows, Mongabay, 25 November, Date of access: 18/11/2020. https://news.mongabay.com/2019/11/indonesia-fires-amazon-carbonemissions-peatland/\#.

Kato, M. D. S., Kato, O. R., Denich, M., and Vlek, P. L., 1999, Fire-free alternatives to slash-and-burn for shifting cultivation in the eastern Amazon region: the role of fertilizers. Field Crops Research, 62(2-3), 225-237.

Kiyono, Y., and Hastaniah, 2000, The role of slash-and-burn agriculture in transforming dipterocarp forest into Imperata grassland. In Rainforest ecosystems of East Kalimantan, edited by E. Guhardja, M. Fatawi, M. Sutisna, T. Mori, and S. Ohta. Ecological Studies (Analysis and Synthesis) (Tokyo: Springer Japan), pp. 199-208. doi: 10.1007/978-4-431-67911-0_17.

Kiyono, Y., Ochiai, Y., Chiba, Y., Asai, H., Saito, K., Shiraiwa, T., Horie, T., Songoukhai, V., Navongxai, V., and Inoue, Y., 2007, Predicting chronosequential changes in carbon stocks of pachymorph bamboo communities in slash-and-burn agricultural fallow, northern Lao People's Democratic Republic. Journal of Forest Research, 12(5), 371-383.

Kotto-Same, J., Woomer, P. L., Appolinaire, M., and Louis, Z., 1997, Carbon dynamics in slash-and-burn agriculture and land use alternatives of the humid forest zone in Cameroon. Agriculture, Ecosystems \& Environment, 65(3), 245-256.

Kotto-Same, J., Woomer, P. L., Appolinaire, M., and Louis, Z., 1997, Carbon dynamics in slash-and-burn agriculture and land use alternatives of the humid forest zone in Cameroon. Agriculture, Ecosystems \& Environment, 65(3), 245-256. doi: https://doi.org/10.1016/S0167-8809(97)00060-1.

Kukla, J., Whitfeld, T., Cajthaml, T., Baldrian, P., Veselá-Šimáčková, H., Novotný, V., and Frouz, J., 2019, The effect of traditional slash-and-burn agriculture on soil organic matter, nutrient content, and microbiota in tropical ecosystems of Papua New Guinea. Land Degradation \& Development, 30(2), 166-177. doi: 10.1002/ldr.3203.

Lasco, R. D., Delfino, R. J. P., and Espaldon, M. L. O., 2014, Agroforestry systems: helping smallholders adapt to climate risks while mitigating climate change. Wiley Interdisciplinary Reviews: Climate Change, 5(6), 825833.

Lehsten, V., Tansey, K., Balzter, H., Thonicke, K., Spessa, A., Weber, U., Smith, B., and Arneth, A., 2009, Estimating carbon emissions from African wildfires, Biogeosciences, 6(3), 349-360. doi: 10.5194/bg-6-3492009.

Lehtonen, H., and Huttunen, P., 1997, History of forest fires in eastern Finland from the fifteenth century ADthe possible effects of slash-and-burn cultivation. The Holocene, 7(2), 223-228.

Liang, J. L., Zhou, W. H., Gao, S. M., Yu, W. P., Shu, W. S., and Li, J. T., 2018, A simple slash-and-char system to mitigate climate change and environmental pollution. Environmental Pollution, 242, 1904-1911.

Lopes, M., 2019, As the Amazon burns, breathing problems spike, The Washington Post, 28 August, Date of access: 20/01/20. https://www.washingtonpost.com/world/the_americas/as-amazon-burns-breathing-problemsspike/2019/08/28/497ed9ec-c908-11e9-9615-8f1a32962e04_story.html.

Mamede, M. de A., and de Araújo, F. S., 2008, Effects of slash and burn practices on a soil seed bank of caatinga vegetation in Northeastern Brazil. Journal of Arid Environments, 72(4), 458-470. doi: https://doi.org/10.1016/j.jaridenv.2007.07.014.

Martorano, L. G., Siviero, M. A., Tourne, D. C. M., Vieira, S. B., Fitzjarrald, D. R., Vettorazzi, C. A., Junior, S.B., Yered, J.A.G., Meyering, E., and Lisboa, L. S. S., 2016, Agriculture and forest: A sustainable strategy in the Brazilian Amazon. Embrapa Amazônia Oriental-Artigo em periódico indexado (ALICE).

Mburu, J., Börner, J., Hedden-Dunkhorst, B., Mendoza-Escalante, A., and Frohberg, K., 2007, Feasibility of mulching technology as an alternative to slash-and-burn farming in eastern Amazon: A cost-benefit analysis. Renewable Agriculture and Food Systems, 22(2), 125-133.

McLauchlan, K. K., 2006, Effects of soil texture on soil carbon and nitrogen dynamics after cessation of agriculture. Geoderma, 136(1-2), 289-299.

Medrilzam, M., Dargusch, P., Herbohn, J., and Smith, C., 2013, The socio-ecological drivers of forest degradation in part of the tropical peatlands of Central Kalimantan, Indonesia. Forestry: An International Journal of Forest Research, 87(2), 335-345. doi: 10.1093/forestry/cpt033. 
Moura, E.G., Sena V. G.L., Correa, M. S., and Aguiar, A. d.CF., 2013, The importance of an alternative for sustainability of agriculture around the periphery of the amazon rainforest. Recent Patents on Food, Nutrition \& Agriculture, 5(1), 70-78.

Myers, N., 1991, Tropical forests: present status and future outlook. Climatic Change, 19(1-2), 3-32.

Normile, D., 2019, Parched peatlands fuel Indonesia's blazes. Science, 366(6461), 2019.

Ohtsuka, T., Mo, W., Uchida, M., Sako, H., and Koizumi, H., 2007, Slash-and-Burn Agriculture in a Japanese Cedar (Cryptomeria japonica D. Don.) Plantation: Effects of Fire on Nutrients and Soil Emissions of Carbon Dioxide. Elsevier Oceanography Series, 73, 395-416.

Palm, C., Tomich, T., Van Noordwijk, M., Vosti, S., Gockowski, J., Alegre, J., and Verchot, L., 2004, Mitigating GHG emissions in the humid tropics: Case studies from the alternatives to slash-and-burn program (ASB). In: Tropical Agriculture in Transition - Opportunities for Mitigating Greenhouse Gas Emissions? edited by R. Wassmann, and P. L. G. Vlek. (Dordrecht, Netherlands: Springer), 145-162. doi: 10.1007/978-94017-3604-6_8.

Panosso, A. R., Marques Jr, J., Pereira, G. T., and La Scala Jr, N., 2009, Spatial and temporal variability of soil $\mathrm{CO}_{2}$ emission in a sugarcane area under green and slash-and-burn managements. Soil and Tillage Research, 105(2), 275-282.

Powlson, D. S., Stirling, C. M., Jat, M. L., Gerard, B. G., Palm, C. A., Sanchez, P. A. and Cassman, K. G., 2014, Limited potential of no-till agriculture for climate change mitigation. Nature Climate Change, 4(8), 678-683.

Randriamalala, J. R., Hervé, D., Letourmy, P., and Carrière, S. M., 2015, Effects of slash-and-burn practices on soil seed banks in secondary forest successions in Madagascar. Agriculture, Ecosystems \& Environment, 199, 312-319. doi: https://doi.org/10.1016/j.agee.2014.09.010.

Reichert, J. M., Bervald, C. M. P., Rodrigues, M. F., Kato, O. R., and Reinert, D. J., 2014, Mechanized land preparation in eastern Amazon in fire-free forest-based fallow systems as alternatives to slash-and-burn practices: hydraulic and mechanical soil properties. Agriculture, Ecosystems \& Environment, 192, 47-60.

Reinhardt, T. E., Ottmar, R. D., and Castilla, C., 2001, Smoke impacts from agricultural burning in a rural Brazilian Town. Journal of the Air \& Waste Management Association, 51(3), 443-450. doi: 10.1080/10473289.2001.10464280.

Rossi, J. P., Celini, L., Mora, P., Mathieu, J., Lapied, E., Nahmani, J., Ponge, J. F., and Lavelle, P., 2010, Decreasing fallow duration in tropical slash-and-burn agriculture alters soil macroinvertebrate diversity: A case study in southern French Guiana. Agriculture, Ecosystems \& Environment, 135(1), 148-154. doi: https://doi.org/10.1016/j.agee.2009.08.012.

Rumpel, C., Alexis, M., Chabbi, A., Chaplot, V., Rasse, D. P., Valentin, C., and Mariotti, A., 2006, Black carbon contribution to soil organic matter composition in tropical sloping land under slash and burn agriculture. Geoderma, 130(1-2), 35-46.

Salisbury, D. S., and Schmink, M., 2007, Cows versus rubber: Changing livelihoods among Amazonian extractivists. Geoforum, 38(6), 1233-1249. doi: https://doi.org/10.1016/j.geoforum.2007.03.005.

Silva, J. M. N., Carreiras, J. M. B., Rosa, I., and Pereira, J. M. C., 2011, Greenhouse gas emissions from shifting cultivation in the tropics, including uncertainty and sensitivity analysis. Journal of Geophysical Research: Atmospheres, 116(D20). doi: 10.1029/2011JD016056.

Smith, J., Van De Kop, P., Reategui, K., Lombardi, I., Sabogal, C., and Diaz, A., 1999, Dynamics of secondary forests in slash-and-burn farming: interactions among land use types in the Peruvian Amazon. Agriculture, Ecosystems \& Environment, 76(2-3), 85-98.

Socolar, J. B., Valderrama Sandoval, E. H., and Wilcove, D. S., 2019, Overlooked biodiversity loss in tropical smallholder agriculture. Conservation Biology, 33(6), 1338-1349. doi: 10.1111/cobi.13344.

Strassburg, B. B., Latawiec, A. E., Barioni, L. G., Nobre, C. A., Da Silva, V. P., Valentim, J. F., Vianna, M., and Assad, E. D., 2014, When enough should be enough: Improving the use of current agricultural lands could meet production demands and spare natural habitats in Brazil. Global Environmental Change, 28, 84-97.

Styger, E., Rakotondramasy, H. M., Pfeffer, M. J., Fernandes, E. C., and Bates, D. M., 2007, Influence of slashand-burn farming practices on fallow succession and land degradation in the rainforest region of Madagascar. Agriculture, Ecosystems \& Environment, 119(3), 257-269. doi: https://doi.org/10.1016/j.agee.2006.07.012.

Tacconi, L., and Vayda, A. P., 2006, Slash and burn and fires in Indonesia: A comment. Ecological Economics, 56(1), 1-4. doi: https://doi.org/10.1016/j.ecolecon.2005.03.034. 
Tan-Soo, J.-S., and Pattanayak, S. K., 2019, Seeking natural capital projects: Forest fires, haze, and early-life exposure in Indonesia. Proceedings of the National Academy of Sciences, 116(12), 5239 - 5245. doi: 10.1073/pnas. 1802876116.

Thomaz, E. L., 2013, Slash-and-burn agriculture: Establishing scenarios of runoff and soil loss for a five-year cycle. Agriculture, Ecosystems \& Environment, 168, 1-6. doi: https://doi.org/10.1016/j.agee.2013.01.008.

Thomaz, E. L., 2017, High fire temperature changes soil aggregate stability in slash-and-burn agricultural systems. Scientia Agricola, 74, 157-162.

Thomaz, E. L., Antoneli, V., and Doerr, S. H., 2014, Effects of fire on the physicochemical properties of soil in a slash-and-burn agriculture. CATENA, 122, 209-215. doi: https://doi.org/10.1016/j.catena.2014.06.016.

Thong, P., Pebam, R., and Sahoo, U. K., 2016, Recovery pattern of vegetation during succession following slash and burn agriculture in Mizoram, North-East India. Journal of Biology \& Soil Health, 3(2), 8.

Tinker, P. B., Ingram, J. S. I., and Struwe, S., 1996, Effects of slash-and-burn agriculture and deforestation on climate change. Agriculture, Ecosystems \& Environment, 58(1), 13-22. doi: https://doi.org/10.1016/01678809(95)00651-6.

Tinker, P. B., Ingram, J. S., and Struwe, S., 1996, Effects of slash-and-burn agriculture and deforestation on climate change. Agriculture, Ecosystems \& Environment, 58(1), 13-22.

Tomich, T. P., van Noordwijk, M., Vosti, S. A., and Witcover, J., 1998, Agricultural development with rainforest conservation: methods for seeking best bet alternatives to slash-and-burn, with applications to Brazil and Indonesia. Agricultural Economics, 19(1-2), 159-174.

Tremblay, S., Lucotte, M., Revéret, J. P., Davidson, R., Mertens, F., Passos, C. J. S., and Romana, C. A., 2015, Agroforestry systems as a profitable alternative to slash and burn practices in small-scale agriculture of the Brazilian Amazon. Agroforestry Systems, 89(2), 193-204.

Trexler, M. C., 1993, Manipulating biotic carbon sources and sinks for climate change mitigation: can science keep up with practice?. Water, Air, and Soil Pollution, 70(1-4), 579-593.

Tschakert, P., Coomes, O. T., and Potvin, C., 2007, Indigenous livelihoods, slash-and-burn agriculture, and carbon stocks in Eastern Panama. Ecological Economics, 60(4), 807-820. doi: https://doi.org/10.1016/j.ecolecon.2006.02.001.

Unruh, J. D., Houghton, R. A., and Lefebvre, P. A., 1993, Carbon storage in agroforestry: an estimate for subSaharan Africa. Climate Research, 3(1-2), 39-52.

van Vliet, N., Mertz, O., Heinimann, A., Langanke, T., Pascual, U., Schmook, B., Adams, C., Schmidt-Vogt, D., Messerli, P., Leisz, S., and Castella, J. C., 2012, Trends, drivers and impacts of changes in swidden cultivation in tropical forest-agriculture frontiers: A global assessment. Global Environmental Change, 22(2), 418-429. doi: https://doi.org/10.1016/j.gloenvcha.2011.10.009.

Vashum, K. T., and Jayakumar, S., 2016, Soil organic carbon status and sustainability of slash-and-burn cultivation in India. Journal of Sustainable Forestry, 35(8), 591-603.

Verchot, L. V., Van Noordwijk, M., Kandji, S., Tomich, T., Ong, C., Albrecht, A., Mackensen, J., Bantilan, C., Anupama, K.V. and Palm, C., 2007, Climate change: linking adaptation and mitigation through agroforestry. Mitigation and Adaptation Strategies for Global Change, 12(5), 901-918.

Vosti, S. A., and Witcover, J., 1996, Slash-and-burn agriculture - household perspectives. Agriculture, Ecosystems \& Environment, 58(1), 23-38. doi: https://doi.org/10.1016/0167-8809(95)00652-4.

Watson, R. T., Noble, I. R., Bolin, B. Ravindranath, N. H., Verardo, D. J., and Doken, D.J. (eds.), 2000, Land use, land-use change and forestry. Intergovermental Panel on Climate Change (Cambridge, UK:, Cambridge University Press).

Woomer, P. L., and Palm, C. A., 1998, An approach to estimating system carbon stocks in tropical forests and associated land uses. The Commonwealth Forestry Review, 181-190.

Ziegler, A. D., Bruun, T. B., Guardiola-Claramonte, M., Giambelluca, T. W., Lawrence, D., and Lam, N. T., 2009, Environmental consequences of the demise in swidden cultivation in montane mainland Southeast Asia: Hydrology and geomorphology, Human Ecology, 37(3), 361-373. doi: 10.1007/s10745-009-9258-x.

Ziegler, A. D., Phelps, J., Yuen, J. Q., Webb, E. L., Lawrence, D., Fox, J. M., Bruun, T.B., Leisz, S.J., Ryan, C.M., Dressler, W., Mertz, O., Pascual, U., Padoch, C., and Koh, L.P., 2012, Carbon outcomes of major land-cover transitions in SE Asia: great uncertainties and REDD+ policy implications. Global Change Biology, 18(10), 3087-3099. 